\title{
Reliability assessment of pollution removal of wastewater treatment plant using the method of Weibull
}

\author{
Karolina Kurek $^{I^{*}}$ Piotr Bugajski ${ }^{1}$, Agnieszka Operacz ${ }^{1}$, Paulina Śliz ${ }^{2}$, Krzysztof \\ Jóźwiakowski ${ }^{3}$, Adelaide Almeida ${ }^{4}$ \\ ${ }^{1}$ University of Agriculture in Krakow, Faculty of Environmental Engineering and Land Surveying, \\ Department of Sanitary Engineering and Water Management, Al. Mickiewicza 21, 31-120 Krakow, \\ Poland \\ ${ }^{2}$ Krakow University of Economics, Rakowicka 27, 31-510 Krakow, Poland \\ ${ }^{3}$ University of Life Sciences in Lublin, Akademicka 13, 20-033 Lublin, Poland \\ ${ }^{4}$ Politechnic Institute of Beja, Department of Technology and Applied Science, Ap 158, 7801-902 \\ Beja, Portugal
}

\begin{abstract}
The aim of study was the analyze of the reliability pollution removal in wastewater treatment plant in Mińsk Mazowiecki. The article presents the results of the reliability of BOD, COD and total suspended solids removal of wastewater treatment plant with actived sludge. Physical and chemical analyses of raw wastewater and treated effluent were carried out in the years 2016-2017 (2 years). The designed size of the treatment plant with actived sludge, expressed in PE is 82200 residents. During this study period, 50 wastewater samples were collected and analyses. For each of pollution indicators descriptive statistic, percentage reduction and and treatment plant reliability factors (WN) were calculated. The average effectiveness of $\mathrm{BOD}_{5}$ (Biochemical Oxygen Demand), $\mathrm{COD}_{\mathrm{Cr}}$ (Chemical Oxygen Demand) and TSS (Total Suspended Solid) removal in this period of study were respectively: $99.1 \%, 96.3 \%$ and $98.9 \%$. A reliability analysis was performed using the Weibull probability model.
\end{abstract}

\section{Introduction}

Poland is one of the most populous and the biggest countries of the Baltic Sea region. According to the newest information from Central Statistical Office in the years from 2000- 2016 the numbers of city which was served by the treatment plant increased by 116 cities (from 801 cities in 2000 to 917 in 2016, what is around 14\%) [1]. The wastewater composition it is the one of the criterion in the choice of treated technology. The concentration and type of pollution in urban sewage is varied and changeable over time but also depends on many factors like - size of agglomeration and the participation of industrial wastewater [2]. Wastewater is a multiphase but also multicomponent system of dissolved gases, liquids and solids. The organic and inorganic compounds exist in sewage may be in the form of solutions, colloids or dispersed phases [3]. To choosing the technology of treated wastewater is necessary to consider economic technical and ecological aspects

* corresponding author: karolina.kurek@urk.edu.pl 
[4]. Improper way of sewage treated can be very danger for environmental safety, also for the groundwater's physicschemical and bacteriological properties $[5$, 6].

Poland is obligated to implement and comply with the regulations of the Water Framework Directive (WFD 2000), for all European Union members. According to the WFD provision that all agglomerations with more than 2000 equivalent inhabitants should be equipped with a collective sewage system, completed with sewage treatment plant $[7,8$,$] . The$ wastewater treatment plants with actived sludge is one of the most commonly used solution for the treated sewage in for community (cities) but for household wastewater treatment plants also, because of the high effectiveness of reduction the pollutions in purification process $[9,10]$.

Reliability is an important aspect in the evaluation of wastewater treatment plant work [11-14]. One of the primary method uses to properly evaluate the reliability of a wastewater treatment plant is Reliability Coefficient (RC). This coefficient is useful to specifying the technical reliability of the object. Moreover, in evaluating the reliability of a wastewater treatment plant work, statistical probability distributions are used to establish the probability of occurrence of selected values and concentration of pollutions indicators. Nowadays, the Weibull distribution is an accurate method for the evaluation of reliability of small and collective wastewater treatment plants
$[15,16]$. The reliability of wastewater treatment plant working with actived sludge, has been widely presented by Eisenberg et al. [17], Oliveira and Von Sperling [18] and Bugajski et al. [19].

\section{Location of the object}

The wastewater treatment plant is located in the Mazowieckie voivodeship in Mińsk Mazowiecki city (Fig. 1). The object is working with the actived sludge technology, which is one of the most popular and effective methods recommended to treated domestic wastes. Wastewater from the city in flow to the sewage treatment plant by the two kind of sewage system: rain water sewer system and sanitary system. The sewage from both kind of system are and treated together. Effluent from the wastewater treatment plant is diverted to Srebrna River. Mean designed daily sewage supply for this object is $Q_{m s}=11500 \mathrm{~m}^{3} \cdot \mathrm{d}^{-1}$. According to the population equivalent (PE) range is equal 82 200. As per the water permit issued in 2015, acceptable concentrations of the analysed parameters in the sewage discharged into a receiver should not exceed $15 \mathrm{mgO}_{2} \cdot \mathrm{dm}^{-3}$ for $\mathrm{BOD}_{5}, 125 \mathrm{mgO} \cdot \mathrm{dm}^{-3}$ for $\mathrm{COD}_{\mathrm{Cr}}, 35$ $\mathrm{mg} \cdot \mathrm{dm}^{-3}$ for TSS.

\section{Materials and Methods}

Additionally, during the two-years study period, 50 samples of raw and treated 

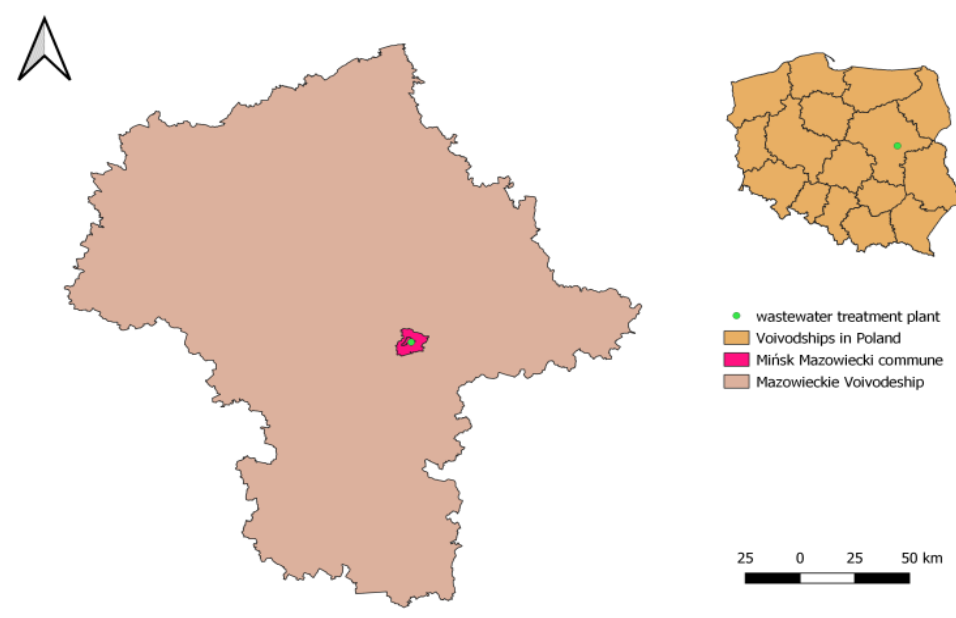

Figure 1. Location of sewage treatment plant in the background of the Mińsk Mazowiecki commune

sewage were collected, and they were subjected to physico-chemical analysis.

The analysis concerned pollution indicators from the basic group: $\mathrm{BOD}_{5}$, $\mathrm{COD}_{\mathrm{Cr}}$ and TSS. Physico-chemical analyses were performed in accordance with the reference methods specified in the standards: for $\mathrm{BOD}_{5}$ - PN-EN 1899 1:2002, for COD $_{\mathrm{Cr}}-$ PN-ISO 6060:2006 and for TSS - PN-EN $872: 2007+$ Ap1: 2007. There were determined such descriptive statistics as: positional measures - minimum, average, median and maximum values, measures of dispersion: standard deviation ( $s$ ) and coefficient of variation $\left(\mathrm{V}_{\mathrm{s}}\right)$, for both daily sewage volume and pollution indicators in sewage flowing into the treatment plant. The efficiency of pollutions removal in the wastewater treatment plant in Mińsk Mazowiecki was determined by employing by Weibull reliability theory. Weibull distribution is characterized by a probability density function (1) with parameters $b, c$ and $\theta$ :

$$
f(x)=\frac{c}{b} \cdot\left(\frac{x-\theta)}{b}\right)^{(c-1)} \cdot e^{-\left(\frac{x-\theta)^{c}}{b}\right.}
$$

where: $\mathrm{x}-$ variable defining the concentration of given contamination indicator in treated sewage,

$\mathrm{b}$ - scale parameter,

$\mathrm{c}$ - shape parameter,

$\theta$ - location parameter.

It is assumed that $\theta<x, b>0, c>0$.

Weibull distribution parameters were estimated by means of maximum likelihood method. The applicability of Weibull distribution to the empirical data was assessed using Hollander Proschan test. The results were analyzed with STATISTICA 13 software.

\section{Study results and discussion}

The determined values of individual statistical parameters for the based pollution indicators in the raw and treated wastewater, were to characterized the dynamics changes of their compositions. Results of the analysis of raw and treated effluent are shown in Table 1. According to the result of the composition of raw sewage, it was found that the concentration of $\mathrm{BOD}_{5}$ was determined 
they varied from 250 to $990 \mathrm{mgO} \cdot \mathrm{dm}^{-3}$, and average value was $485.5 \mathrm{mgO} \cdot \mathrm{dm}^{-3}$.

Table 1. Composition of wastewater and pollutant reduction in the wastewater treatment plant in Mińsk Mazowiecki

\begin{tabular}{c|c|c|c|c|c|c|c|c}
\hline \multirow{2}{*}{ Parameters } & \multicolumn{6}{|c}{ Inflow } \\
\cline { 2 - 8 } & Min & Max & Average & Me & $\mathrm{s}$ & $\mathrm{Vs}$ & $\begin{array}{c}\text { Efficiency } \\
{[\%]}\end{array}$ \\
\hline $\begin{array}{c}\mathrm{BOD}_{5} \\
\mathrm{mgO}_{2} \cdot \mathrm{dm}^{-3}\end{array}$ & 250.0 & 990.0 & 485.5 & 400 & 208.2 & 0.43 & - \\
\hline $\begin{array}{c}\mathrm{COD}_{\mathrm{Cr}} \\
\mathrm{mgO}_{2} \cdot \mathrm{dm}^{-3}\end{array}$ & 468.0 & 3150.0 & 1177.4 & 857 & 704.7 & 0.60 & - \\
\hline $\begin{array}{c}\mathrm{TSS} \\
\mathrm{mg} \cdot \mathrm{dm}^{-3}\end{array}$ & 100.0 & 1600.0 & 513.5 & 390 & 340.8 & 0.66 & - \\
\hline $\begin{array}{c}\mathrm{BOD} \\
\mathrm{mgO}_{2} \cdot \mathrm{dm}^{-3}\end{array}$ & 3.0 & 8.0 & 3.8 & 4 & 0.9 & 0.26 & 99.1 \\
\hline $\begin{array}{c}\mathrm{COD} \mathrm{Cr}^{-3} \\
\mathrm{mgO}_{2} \cdot \mathrm{dm}^{-3}\end{array}$ & 20.1 & 64.0 & 33.8 & 32.9 & 8.7 & 0.26 & 96.3 \\
\hline $\begin{array}{c}\mathrm{TSS} \\
\mathrm{mg}^{2} \cdot \mathrm{dm}^{-3}\end{array}$ & 2.0 & 25.0 & 4.3 & 3.7 & 3.2 & 0.76 & 98.9 \\
\hline
\end{tabular}

For the second of organic pollution indicator (COD), values ranged from 468 to $3150 \mathrm{mgO}_{2} \cdot \mathrm{dm}^{-3}$, and average value equal $1177.4 \mathrm{mgO}_{2} \cdot \mathrm{dm}^{-3}$. In case of concentration of the total suspended solid in raw sewage was formed in the range from 100 to $1600 \mathrm{mg} \cdot \mathrm{dm}^{-3}$, at the average value equal $513.5 \mathrm{mg} \cdot \mathrm{dm}^{-3}$. The results of pollution indicators in raw sewage are while similar to the range of their values given by Kaczor (2009), which confirms that these are typically domestic sewage. According to Mucha (1999) classification the value of the coefficient of variation of all pollution indicators in raw sewage, was on the high variability level. Based on the results of organic pollutions in the outflow from the wastewater treatment plant found that the minimum value of $\mathrm{BOD}_{5}$ was equal $3 \mathrm{mgO}_{2} \cdot \mathrm{dm}^{-3}$, when the maximum was $8 \mathrm{mgO}_{2} \cdot \mathrm{dm}^{-3}$. Average volume for this pollution indicator was $3.8 \mathrm{mgO}_{2} \cdot \mathrm{dm}^{-3}$. Interval between minimum and maximum value of COD was $43.9 \mathrm{mgO}_{2} \cdot \mathrm{dm}^{-3}$, and average value equal
$33.8 \mathrm{mgO}_{2} \cdot \mathrm{dm}^{-3}$. The average concentration of TSS in effluent of wastewater treatment plant was $4.3 \mathrm{mg} \cdot \mathrm{dm}^{-3}$, the range between

minimum and maximum value was equal $23 \mathrm{mg} \cdot \mathrm{dm}^{-3}$. The value of coefficient of variation for $\mathrm{BOD}_{5}$ and COD in outflow, was on the average variability level. For TSS the coefficient of variation shaped on the high variability level for this pollution indicator in outflow [20]. The average pollution removal efficiency was high at $99.1 \%, 96.3 \%$ and $98.9 \%$ for $\mathrm{BOD}_{5}$, $\mathrm{COD}_{\mathrm{Cr}}$ and TSS respectively. Additionally, to analyze wastewater susceptibility to biological degradation, the $\mathrm{COD}_{\mathrm{Cr}} / \mathrm{BOD}_{5}$ ratio was calculated for both influent and effluent. In figure 2 was presented the results of analyze. According to the assessment presented by Miksch and Sikora [20], it can be observed, that for raw sewage biodegradability was on average level in research period. After the biological treated, was observed the increase of $\mathrm{COD}_{\mathrm{Cr}} / \mathrm{BOD}_{5}$ ratio in outflow. 
Increase of $\mathrm{COD}_{\mathrm{Cr}} / \mathrm{BOD}_{5}$ ratio after biological treated process, indicates a high degree of reduction of organic compounds and the residue of hard-biodegradable compounds in outflow. This results indicate, the wastewater treatment plant in Mińsk Mazowieski worked properly in research period. Similar results was presented by Młyńska et al. [2017] [21]. In the paper authors observed the increase of $\mathrm{COD}_{\mathrm{Cr}} / \mathrm{BOD}_{5}$ ratio in wastewater after mechanical and biological treatment. Also results presented by Myszograj i in. [2017] [22], for five wastewater treatments plants with mechanical and biological treatment, confirm that, observed increase of relation between $\mathrm{COD}_{\mathrm{Cr}}$ and $\mathrm{BOD}_{5}$ indicate the high efficiency of organic compounds decomposition in bioreactor. Determine the $\mathrm{COD}_{\mathrm{Cr}} / \mathrm{BOD}_{5}$ ratio in particular stage of treated process can be simple way to definite the working quality in wastewater treatment plant.

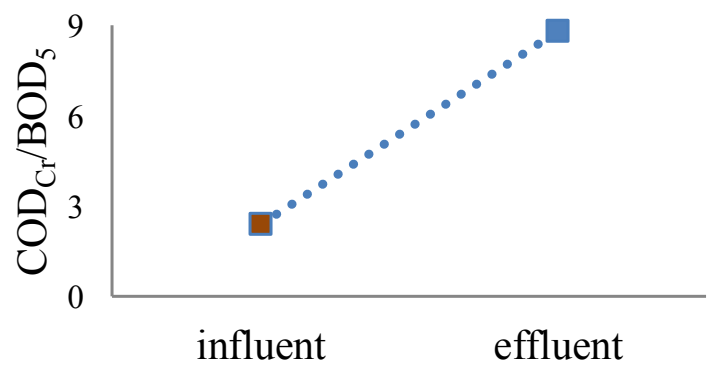

Figure 2. A susceptibility of the raw sewage and treated sewage on biodegradability based on $\mathrm{COD}_{\mathrm{Cr}} / \mathrm{BOD}_{5}$ ration

Further analysis included a verification of the hypothesis that empirical data of pollutant indicators could be described by the Weibull distribution. The results of the Hollander-Proschan test are presented in table 2.The reliability analysis was performed for each pollutant indicators, and the results of the analysis are shown in figure 3.

Analyzing the results of the estimation of the Weibull distribution parameters along to the measures of goodness matching the empirical data, it founded that the Weibull distribution describes empirical data at the significance level $\alpha=0.05$ in the case of: $\mathrm{BOD}_{5}$, COD and TSS, respectively with the probability of $69 \%, 62 \%$ and $94 \%$.

Based on the $\mathrm{BOD}_{5}$ distribution

Table 2. Results of the estimation of the Weibull distribution and the measure of goodness of fit to empirical data

\begin{tabular}{|l|l|l|l|l|l|}
\hline \multirow{2}{*}{ Index } & \multicolumn{2}{|l|}{$\begin{array}{l}\text { Distribution } \\
\text { parameters }\end{array}$} & \multicolumn{2}{l|}{$\begin{array}{l}\text { Hollander- } \\
\text { proschan test }\end{array}$} \\
\cline { 2 - 6 } & $\mathrm{b}$ & $\mathrm{c}$ & $\theta$ & $\begin{array}{l}\text { Test } \\
\text { value }\end{array}$ & $\mathrm{p}$ \\
\hline $\mathrm{BOD}_{5}$ & 4.2 & 3.6 & 0.0 & 0.39 & 0.69 \\
\hline $\mathrm{COD}$ & 37.1 & 3.8 & 0.0 & 0.49 & 0.62 \\
\hline $\mathrm{TSS}$ & 4.8 & 1.6 & 0.0 & 0.06 & 0.94 \\
\hline
\end{tabular}

Notation: $b$ - scale parameter, $c$ - shape parameter, $\theta$ - location parameter; $p$ - probability value, when $\mathrm{p} \leq 0.05$ the distribution of data is not Weibull distribution.

a)

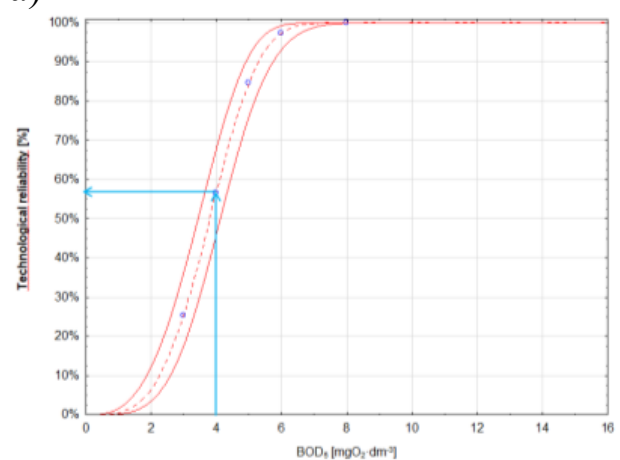

b)

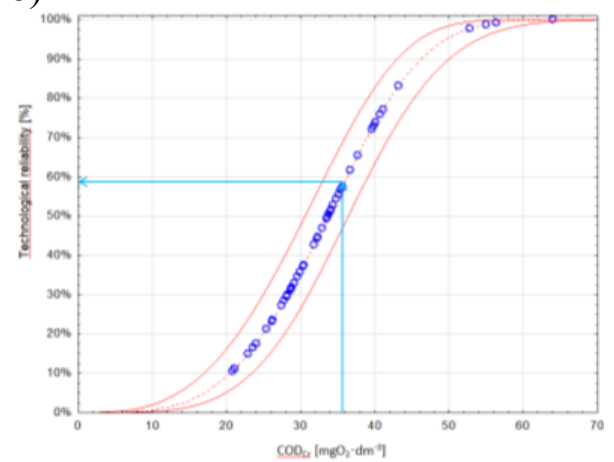

c) 


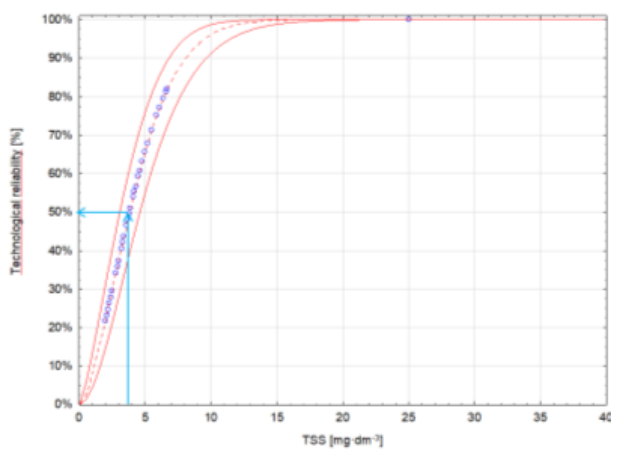

Figure 3. Results of the Weibull reliability analysis for: a) $\mathrm{BOD}_{5}$, b) $\mathrm{COD}_{\mathrm{Cr}}$ and c) TSS in treated wastewater

(fig. 3a) in treated wastewater, it was found that the reliability of the wastewater treatment plant according to the $\mathrm{BOD}_{5}$ median was $69 \%$. This mean that in an annual period, for approximately 245 days, the $\mathrm{BOD}_{5}$ value in outflow will be $\leq 4 \mathrm{mgO}_{2} \cdot \mathrm{dm}^{-3}$. For the second of organic pollutant indicator - $\mathrm{COD}_{\mathrm{Cr}}$ (fig. 3b) reliability effectiveness relative to the median in the outflow, was $62 \%$. That is mean, that the value equal or less than $32.9 \mathrm{mgO}_{2} \cdot \mathrm{dm}^{-3}$ appear in outflow around 226 days in one year period. Result of Weibull distribution for the total suspended solid, indicates the $94 \%$ work reliability, relative to median. Therefore, in the treated wastewater the median value of TSS $\left(3.7 \mathrm{mg} \cdot \mathrm{dm}^{-3}\right)$ appear in almost 342 days per year. According to the recommendations presented in Andraka and Dzienis [2010] work, the wastewater treatment plant under $50000 \mathrm{PE}$, should work at the reliability of at least $93.7 \%$ with operator risk equal $\alpha=0.05$. Therefore, as per this recommendations, the acceptable failure rate for such object is only 22 days per year. It is mean, that during the two years of operation limit for $\mathrm{BOD}_{5}, \mathrm{COD}_{\mathrm{Cr}}$ and TSS had never been exceeded. It is worth noting that the analysed object achieved in the research period high effectiveness of removing contaminants. For all the indicators the average of effects were around $95 \%$ (table 1).

\section{Conclusions}

According to the results of performed reliability analysis for the collective treatment plant in Mińsk Mazowiecki, presented general conclusions and summary:

1. The average efficiencies of $\mathrm{BOD}_{5}$, COD and TSS removal in two years of this operation were: $99.1 \%$, $96.3 \%$, and $98.9 \%$, respectively.

2. The average values of pollutants in the effluent measured by $\mathrm{BOD}_{5}$, COD and TSS were $3.8 \mathrm{mgO}_{2} \cdot \mathrm{dm}^{-3}$, $33.8 \mathrm{mgO}_{2} \cdot \mathrm{dm}^{-3}$ and $4.3 \mathrm{mg} \cdot \mathrm{dm}^{-3}$, respectively, and were much below the requirements of the acceptable limit, which are $15 \mathrm{mgO}_{2} \cdot \mathrm{dm}^{-3}$ for $\mathrm{BOD}_{5}, 125 \mathrm{mgO}_{2} \cdot \mathrm{dm}^{-3}$ for COD, and $35 \mathrm{mg} \cdot \mathrm{dm}^{-3}$ for TSS.

3. The reliability levels set were significantly lower than those proposed in the literature source.

4. The reliability of the investigation of wastewater treatment plant with actived sludge during the exploitation period of two years was acceptable in accordance with Polish standards.

\section{Acknowledgements}

Publication is funded by the Polish National Agency for Academic Exchange under the International Academic Partnerships Programme from the project „Organization of the 9th International Scientific and Technical Conference entitled Environmental Engineering, Photogrammetry, Geoinformatics Modern Technologies and Development Perspectives".

This research was financed by the Ministry of Science and High Education of the Republic of Poland 


\section{References}

[1.] GUS. Municipal Infrastructure in 2017; Główny Urząd Statystyczny: Warszawa, Poland, (2017)

[2.] E. Płuciennik-Koropczuk, A. Jakubaszek. Inżynieria Środowiska, 28, 73-83(2012)

[3.] T. Siwiec, L. Reczek, M.M. Michel, B. Gut, B. Hawer-Strojek, J. Czajkowska, K. Jóźwiakowski, M. Gajewska, P. Bugajski. Archives of Environmental Protection, Vol. 44 (4), p. 50-57 (2018)

[4.] P. Bugajski, K. Kurek, D. Młyński, A. Operacz. Journal of Water and Land Development, 40 (I-III), p. 155160 (2019)

[5.] A. Operacz, K. Kurek, D. Młyński, P. Bugajski. Journal of Ecological Engineering, 20 (2), p. 67-76 (2019)

[6.] H.D. Sharma, K.R. Reddy. John Wiley \& Sons, Hoboken, New Jersey (2004)

[7.] K. Kurek, P. Bugajski, D. Młyński, E. Nowobilska-Majewska. Journal of Ecological Engineering, Vol. 20 (1), p. 39-45 (2019)

[8.] W. Miernik, D. Młyński. Episteme, 22, p. 303-310 (2014)

[9.] J. Pawełek, P. Bugajski. Acta Scientiarum Polonorum Formatio Circumiectus, 16, 3-14 (2017)
[10.] M. Marzec, K. Jóźwiakowski, A. Dębska, M. Gizińska Górna, A. Pytka-Woszczyło, A. KowalczykJuśko, A. Listosz. Water, vol. 10, p. 1445 (2018)

[11.] K. Jóźwiakowski, Z. Mucha, A. Generowicz, S. Baran, J. Bielińska, W. Wójcik. Arch. Environ. Prot., 3, pp. 76-82 (2015)

[12.] J. Mikosz. Desalinat. Water Treat., 51 (10-12), pp. 2461-2466 (2013)

[13.] K. Kołecka, M. Gajewska, H. Obarska-Pempkowiak. Chapter Role Natur. Construct. Wetlands Nut. Cycl. Retent. Lands., 18, pp. 259-273 (2015)

[14.] K. Jóźwiakowski, P. Bugajski, Z. Mucha, W. Wójcik, A. Jucherski, M. Nastawny, T. Siwiec, A. Mazur, R. Obroślak, M. Gajewska. Separation and purification technology. Vol.187, pp. 60-66, (2017)

[15.] P. Bugajski, A. Wałęga, G. Kaczor. Gaz, Woda i Rechnika Sanitarna, 2, pp. 56-58 (2012)

[16.] P. Bugajski. Ecol. of Rur. Are., II (3), pp. 667-677 (2014)

[17.] D. Eisenberg, J. Soller, R. Sakaji, A. Olivieri. Water Sci. Technol., 43 (10), pp. 91-99 (2001)

[18.] S.C. Oliveira, M. Von. Water Res., 42 (4-5), pp. 1182-1194 (2008)

[19.] P. Bugajski, K. Chmielowski, G. Kaczor. J. Ecol. Eng., 17 (4), pp. 143-147 (2016)

[20.] K. Miksch, J. Sikora. Biotechnologia ścieków. Wydawnictwo Naukowe PWN, Warszawa (2010)

[21.] A. Młyńska, K. Chmielowski, D. Młyński. Inżynieria Ekologiczna. Vol. 18 (5), pp. 18-26. (2017)

[22.] S. Myszograj, E. PłuciennikKoropczuk, A. Jakubaszek, A. 
Świętek. Civil and Environmental Engineering Reports. Vol. 24(1), pp. 195-206 (2017)

[23.] D. Andraka, L. Dzienis. Zesz. Nauk. P. Białost. Inż. Środ., 16, 24-28 (2003) 